\title{
PENGARUH PEMBERIAN SEKAM PADI TANPA DAN DENGAN FERMENTASI YANG DISUPLEMENTASI DAUN SIRIH DALAM RANSUM TERHADAP BOBOT POTONG, NON KARKAS EKSTERNAL, DAN LEMAK ABDOMINAL ITIK BALI BETINA
}

\author{
BAYU ANGGARA, I W., I. B. G. PARTAMA, DAN A. A. A. S. TRISNADEWI \\ Program Studi Sarjana Peternakan, Fakultas Peternakan, Universitas Udayana \\ e-mail: wayanbayuanggara@gmail.com
}

\begin{abstract}
ABSTRAK
Penelitian bertujuan untuk mengetahui pengaruh pemberian sekam padi tanpa dan dengan fermentasi yang disuplementasi daun sirih (piper betle L) dalam ransum terhadap bobot potong, non karkas eksternal dan lemak abdominal itik bali betina umur 24 minggu. Penelitian dilaksanakan di Desa Guwang, Kecamatan Sukawati, Kabupaten Gianyar selama 12 minggu, dengan menggunakan rancangan acak lengkap (RAL) yang terdiri dari lima perlakuan dengan 4 ulangan dan setiap ulangan berisi 4 ekor itik. Adapun perlakuan tersebut adalah: A kontrol (ransum tanpa tambahan sekam padi, sekam padi fermentasi dan daun sirih), B (ransum mengandung 12,5\% sekam padi), $\mathrm{C}$ (ransum mengandung $12,5 \%$ sekam padi fermentasi), D (ransum mengandung $12,5 \%$ sekam padi dan $1 \%$ daun sirih) dan E (ransum mengandung 12,5\% sekam padi fermentasi dan 1\% daun sirih). Variabel yang diamati adalah bobot potong, non karkas eksternal dan lemak abdominal. Hasil penelitian menunjukkan bahwa pemberian ransum mengandung 12,5\% sekam padi fermentasi dan disuplementasi $1 \%$ daun sirih berpengaruh nyata $(\mathrm{P}<0,05)$ terhadap bobot potong, non karkas dan lemak abdominal. Berdasarkan hasil penelitian dapat disimpulkan bahwa pemberian sekam padi tanpa dan dengan fermentasi yang disuplemetasi daun sirih (Piper betle L) dalam ransum dapat meningkatkan bobot potong dan bobot non kerkas eksternal tetapi menurunkan berat lemak abdominal itik bali betina.
\end{abstract}

Kata kunci: sekam padi, daun sirih, bobot potong, non karkas eksternal, itik bali betina

$$
\begin{aligned}
& \text { THE EFFECT OF RICE HULL WITHOUT AND WITH FERMENTED WHICH } \\
& \text { SUPLEMENTED WITH BETLE LEAVES IN RATION TO SLAUGHTERING WEIGHT, } \\
& \text { EXTERNAL NON CARCASS, AND ABDOMINAL FAT OF FEMALE BALI DUCK }
\end{aligned}
$$

\begin{abstract}
The aim of this study was determined the effect of rice hull without and with fermented which supplemented with betel leaf (Piper betle L.) in the ration on slaughtering weight, non-external carcass and abdominal fat of female bali duck age 24 weeks. The study was held in Guwang Villag, Sukawati sub-district, Gianyar district for 12 week, the study was conducted using a completely randomized design (CRD) consisting of five treatments with 4 replications and each replication contains 4 duck, as for the treatment is: A control (without rice hull, fermented rice hull and betel leaf, B (ration contain 12.5\% rice hull), C (ration contain 12.5\% fermented rice hull), D (ration contain 12,5\% rice hull and $1 \%$ betel leaf) and $\mathrm{E}$ (ration contain 12,5\% fermented rice hull and 1\% betel leaf). Variables observed were slaughtering weight, external non-carcass and abdominal fat. The results showed that giving ration contained of $12.5 \%$ fermented rice hull and supplemented with $1 \%$ betel leaf was significantly different on slaughtering weight, non-carcass, and abdominal fat. It was concluded that giving of fermented rice hull and supplemented with betel leaf in ration of bali duck could increase slaughtering weight and external non carcass but decreased abdominal fat.
\end{abstract}

Keywords: rice hull, betle leaf, slaughter weight, non carcass external, female bali duck 


\section{PENDAHULUAN}

Itik bali memiliki peluang besar untuk dikembangkan karena memiliki keunggulan, diantaranya memiliki daya tahan hidup yang tinggi sehingga dapat dipelihara di berbagai tempat di Indonesia. Walaupun itik bali dipelihara di lingkungan yang kurang baik, itik bali masih bisa bertahan hidup. Itik bali dapat dipelihara secara terkurung dengan ransum kering yang kandungan nutriennya seimbang dan tanpa dukungan kolam penggembalaan (Murtidjo, 2006).

Kebutuhan daging itik di Bali semakin meningkat seiring dengan banyaknya minat masyarakat lokal maupun mancanegara terhadap olahan daging itik bali. Direktorat Jenderal Peternakan dan Kesehatan Hewan (2016) menyatakan bahwa populasi itik di Indonesia setiap tahun mengalami peningkatan. Populasi itik pada tahun 2015 tercatat 45.322.00o ekor dan tahun 2016 meningkat menjadi 47.360.00o ekor. Populasi itik di Bali tahun 2016 tercatat 674.094 ekor. Produksi daging itik di Bali tahun 2015 tercatat 364 ton, sedangkan tahun 2016 mengalami peningkatan yaitu 378 ton. Meningkatnya kebutuhan daging itik setiap tahunnya menyebabkan peningkatan minat masyarakat dalam beternak itik.

Pakan memegang peranan penting dalam usaha peternakan itik. Setioko dan Rohaeni (2001) yang melakukan penelitian pada itik Alabio sebanyak 1080 ekor melaporkan bahwa rataan porsi biaya pakan untuk produksi telur selama 12 bulan sebanyak 77,0\% dengan kisaran antara 75,79 - 77,70\%. Morran dan Orr (1970) menyatakan bahwa pertumbuhan merupakan salah satu faktor yang perlu diperhatikan sebab produksi ternak seperti daging dan telur dalam usaha peternakan tergantung dari pemeliharaan pada masa pertumbuhan. Pertumbuhan merupakan suatu proses yang terjadi pada semua makhluk hidup sebagai pertambahan bobot organ atau jaringan tubuh seperti tulang, daging, dan lemak (Lawrence, 1980).

Bagian-bagian tubuh unggas terdiri atas bagian karkas dan bagian non karkas. Non karkas merupakan hasil pemotongan ternak selain karkas. Menurut Resnawati dan Hardjosworo (1976), bagian-bagian non karkas adalah bagian-bagian yang hilang pada waktu pemotongan dan pembersihan yang meliputi bulu, darah, kepala, leher, kaki, dan organ dalam. Komponen sisa karkas terdiri atas organ internal dan organ eksternal. Organ internal terdiri atas hati, jantung dan paru-paru, sedangkan yang termasuk organ eksternal adalah kepala, kulit, dan kaki (Whytes dan Ramsay, 1979).

Muchtadi dan Sugiyono (1992) menyatakan bahwa sekam padi adalah salah satu hasil dari limbah pertanian yang biasa dimanfaatkan sebagai bahan pakan alternatif. Sekam padi memiliki kadar air 12,5\%, serat kasar 35\%, lemak 2,7\%, protein 3,1\%, dan abu $17,5 \%$ dengan kecernaan yang sangat rendah. Kendala utama dari sekam padi sebagai salah satu bahan pakan yaitu nilai nutrisi rendah ditandai oleh kandungan serat kasar tinggi, protein dan energi rendah. Penggunaan sekam padi secara langsung atau sebagai pakan tunggal tidak dapat memenuhi asupan yang sesuai dengan kebutuhan ternak. Close dan Menke (1986) menyatakan rendahnya kecernaan oleh tingginya kandungan silika dan lignin serta adanya ikatan lignoselulosa, dan jika dikonsumsi oleh ternak akan sulit untuk dicerna bahkan dapat menimbulkan gangguan pencernaan dan produksi ternak. Hal tersebut dapat diatasi dengan menggunakan mikroba melalui proses bioteknologi fermentasi. Salah satu bioteknologi fermentasi yang dapat digunakan ialah bioteknologi "Effective Microorganisms" (EM). Hal ini sejalan dengan pendapat Judoamidjojo et al. (1989), bahwa dalam proses fermentasi akan terjadi peningkatan jumlah massa sel yang nantinya akan meningkatkan kadar protein dalam substrat.

Daun sirih (Piper betle L.) merupakan tanaman obatobatan yang mempunyai zat gizi tinggi, mengandung zat anti bakteri, serta tidak berbahaya bagi kesehatan. Pemberian daun sirih pada ransum memberikan akumulasi lemak yang rendah. Turunnya akumulasi lemak disebabkan oleh zat aktif yang ada dalam daun sirih. Fraksi air dari daun sirih mengandung senyawa polar yaitu flavonoid yang merupakan senyawa fenol alami. Susilaetal.(2015) mencoba pemberian sekam padi dengan taraf $5 \%, 10 \%$ dan $15 \%$ baik yang terfermentasi atau tanpa fermentasi disuplementasi daun ubi jalar ungu (Ipomoea batatas L.) diperoleh pemberian 10\% sekam padi terfermentasi dan disuplementasi daun ubi jalar dapat meningkatkan efisiensi penggunaan ransum dan dapat memperbaiki profil lipida daging itik bali. Yadnya dan Wirawan (2016) telah meneliti pemberian sekam padi dalam ransum yang mengandung daun mengkudu (Morinda citrifolia L.) disuplementasi dengan multi enzim dan vitamin dapat meningkatkan produksi telur dan memperbaiki profil lipida telur pada itik.

Berdasarkan permasalahan di atas, maka perlu dilakukan penelitian untuk mengetahui pengaruh pemberian sekam padi fermentasi yang disuplemetasi daun sirih (Piper betle L.) dalam ransum terhadap bobot potong, non karkas dan lemak abdominal itik bali betina.

\section{MATERI DAN METODE}

\section{Materi}

Penelitian dilaksanakan di Desa Guwang, Kabupaten Gianyar, Bali selama 12 minggu. Itik yang digunakan dalam penelitian ini adalah itik bali betina umur 12 minggu. 
Kandang yang digunakan dalam penelitian ini adalah kandang dengan sistem koloni (colony battery) dengan menggunakan bahan dasar kayu dan bambu, yang berlantai dua dan terdiri atas 20 petak kandang. Kandang dilengkapi dengan tempat makanan dan tempat minuman yang terbuat dari bilah-bilah bambu yang letaknya di sebelah luar dan juga dilengkapi dengan tempat penampung kotoran serta penampung sisa makanan, dan juga dilengkapi dengan lampu untuk penerangan di waktu malam.

Komposisi bahan penyusun ransum dapat dilihat pada Tabel 1 dan komposisi nutrien dalam ransum dapat dilihat pada Tabel 2.

Tabel 1. Komposisi bahan penyusun ransum penelitian

\begin{tabular}{lccccc}
\hline \multirow{2}{*}{ Bahan ransum (\%) } & \multicolumn{5}{c}{ Perlakuan } \\
\cline { 2 - 6 } & $\mathrm{A}$ & $\mathrm{B}$ & $\mathrm{C}$ & $\mathrm{D}$ & $\mathrm{E}$ \\
\hline Jagung kuning & 55,36 & 48,34 & 48,34 & 47,34 & 47,34 \\
Konsentrat 144 & 9,37 & 12,36 & 12,36 & 12,36 & 12,36 \\
Bungkil Kelapa & 11,31 & 7,82 & 7,82 & 7,82 & 7,82 \\
Tepung Ikan & 10,13 & 10,29 & 10,29 & 10,29 & 10,29 \\
Dedak Padi & 13,18 & 5,54 & 5,54 & 5,54 & 5,54 \\
Sekam Padi & - & 12,50 & - & 12,50 & - \\
Sekam padi fermentasi & - & - & 12,50 & - & 12,50 \\
Daun sirih & - & - & - & 1 & 1 \\
Mineral B12 & 0,50 & 0,50 & 0,50 & 0,50 & 0,50 \\
NaCl & 0,15 & 0,15 & 0,15 & 0,15 & 0,15 \\
Minyak kelapa & - & 2,5 & 2,5 & 2,5 & 2,5 \\
Total & 100 & 100 & 100 & 100 & 100 \\
\hline
\end{tabular}

Keterangan:

A: Ransum tanpa tambahan sekam padi, sekam padi fermentasi dan daun sirih

B: Ransum mengandung 12,5\% sekam padi

C: Ransum mengandung $12,5 \%$ sekam padi fermentasi

D: Ransum mengandung $12,5 \%$ sekam padi dan $1 \%$ daun sirih

E: Ransum mengandung $12,5 \%$ sekam padi fermentasi dan $1 \%$ daun sirih

\section{Metode}

Rancangan percobaan yang digunakan dalam penelitian ini adalah rancangan acak lengkap (RAL) yang terdiri atas lima perlakuan yaitu; A: ransum tanpa tambahan sekam padi, sekam padi fermentasi dan daun sirih; B: ransum mengandung $12,5 \%$ sekam padi; C: ransum mengandung $12,5 \%$ sekam padi fermentasi; D: ransum mengandung $12,5 \%$ sekam padi dan $1 \%$ daun sirih; E: ransum mengandung 12,5\% sekam padi fermentasi dan $1 \%$ daun sirih. Setiap perlakuan diulang sebanyak empat kali dan setiap ulangan berisi empat ekor itik bali betina, sehingga total itik bali betina yang digunakan adalah $5 \times 4 \times 4=80$ ekor. Ransum dan air minum diberikan secara ad libitum.

Variabel yang akan diamati dalam penelitian ini adalah sebagai berikut:

1. Bobot potong, diperoleh dengan menimbang itik pada akhir penelitian dan sebelumnya itik sudah dipuasakan selama 12 jam.

2. Non karkas eksternal, terdiri atas darah, kepala, kaki,dan bulu.

3. Lemak abdominal, merupakan gabungan dari lemak perut, lemak usus dan lemak empedal

Data yang diperoleh dianalisis dengan sidik ragam, jika diantara perlakuan terdapat perbedaan yang nyata $(\mathrm{P}<0,05)$ analisis dilanjutkan dengan uji jarak berganda dari Duncan (Steel dan Torrie, 1991).

\section{HASIL DAN PEMBAHASAN}

Hasil penelitian menunjukkan bahwa perlakuan B dan $\mathrm{D}$ tidak berpengaruh terhadap rataan bobot potong dibandingkan perlakuan A karena konsumsi ransum pada perlakuan $\mathrm{B}$ dan $\mathrm{D}$ tidak berbeda nyata dengan pemberian perlakuan A(Lampiran 1). Pemberian ransum mengandung 12,5\% sekam padi fermentasi (perlakuan C) dan disuplementasi $1 \%$ daun sirih (perlakuan E) meningkatkan bobot potong itik secara nyata $(\mathrm{P}<0,05)$. Peningkatan bobot potong disebabkan sekam padi yang difermentasi dengan EM-4 mengandung mikroba yang membantu proses pencernaan ransum sehingga zatzat makanan lebih banyak tersedia dan lebih banyak dimanfaatkan dan diserap di saluran pencernaan itik. Bakteri Lactobacillus memberi pengaruh yang menguntungkan melalui produksi asam organik yang

Tabel 2 Komposisi nutrien dalam ransum

\begin{tabular}{|c|c|c|c|c|c|c|c|}
\hline \multirow{2}{*}{\multicolumn{2}{|c|}{ Nutrien }} & \multicolumn{5}{|c|}{ Perlakuan } & \multirow{2}{*}{$\begin{array}{c}\text { Standard } \\
\text { Scott et } \\
\text { al. (1969) }\end{array}$} \\
\hline & & $A$ & $\mathrm{~B}$ & $\mathrm{C}$ & $\mathrm{D}$ & $E$ & \\
\hline Energi metabolisme & kkal/kg & 2884,16 & 2859,08 & 2900,00 & 2858,32 & 2865,45 & $2800-2900$ \\
\hline Protein kasar (PK) & $\%$ & 17,46 & 17,00 & 17,37 & 17,31 & 17,31 & $15-17$ \\
\hline Lemak kasar (LK) & $\%$ & 5,94 & 6,08 & 5,63 & 5,92 & 5,94 & $3-6$ \\
\hline Serat kasar (SK) & $\%$ & 4,63 & 8,23 & 7,34 & 8,84 & 7,24 & $6-9$ \\
\hline Kalsium (Ca) & $\%$ & 0,90 & 0,87 & 0,99 & 0,87 & 0,89 & 0,80 \\
\hline Fosfor $(P)$ & $\%$ & 0,69 & 0,67 & 0,66 & 0,67 & 0,65 & 0,45 \\
\hline
\end{tabular}

\section{Keterangan :}

A: Ransum tanpa tambahan sekam padi, sekam padi fermentasi dan daun sirih

B: Ransum mengandung $12,5 \%$ sekam padi

C: Ransum mengandung $12,5 \%$ sekam padi fermentasi

D: Ransum mengandung $12,5 \%$ sekam padi dan $1 \%$ daun sirih

E: Ransum mengandung $12,5 \%$ sekam padi fermentasi dan $1 \%$ daun sirih 
Tabel 3. Pemberian sekam padi fermentasi yang disuplementasi daun sirih (Piper betle L.) dalam ransum terhadap bobot potong, non karkas eksternal dan lemak abdominal tubuh itik bali betina

\begin{tabular}{|c|c|c|c|c|c|c|c|}
\hline \multirow{2}{*}{ Variabel yang diamati } & \multicolumn{6}{|c|}{ Perlakuan $^{1)}$} & \multirow{2}{*}{ SEM $^{2}$} \\
\hline & & A & B & C & $\mathrm{D}$ & $E$ & \\
\hline Bobot potong & (g/ekor) & $1202,00^{b}$ & $1190,00^{b}$ & $1345,00^{a}$ & $1213,50^{b}$ & $1356,00^{a}$ & 11,45 \\
\hline Bobot darah & (g/ekor) & $94,75^{a}$ & $91,75^{a}$ & $94,75^{a}$ & $95,00^{a}$ & $96,00^{a}$ & 1,71 \\
\hline Bobot kepala & (g/ekor) & $64,00^{c}$ & $69,00^{b c}$ & $69,25^{b c}$ & $76,00^{a}$ & $72,00^{a b}$ & 2,08 \\
\hline Bobot kaki & (g/ekor) & $35,00^{b}$ & $36,75^{a b}$ & $38,00^{a}$ & $37,25^{a b}$ & $39,25^{a}$ & 0,89 \\
\hline Bobot bulu & (g/ekor) & $116,75^{b}$ & $121,75^{a}$ & $123,50^{a}$ & $123,75^{a}$ & $123,00^{a}$ & 1,44 \\
\hline Bobot lemak perut & (g/ekor) & $24,25^{a}$ & $20,50^{b}$ & $18,75^{\mathrm{C}}$ & $19,50^{\mathrm{bc}}$ & $18,50^{\mathrm{C}}$ & 0,48 \\
\hline Bobot lemak usus & (g/ekor) & $10,00^{c}$ & $11,75^{a}$ & $10,75^{b}$ & $12,00^{a}$ & $9,25^{d}$ & 0,19 \\
\hline Bobot lemak empedal & (g/ekor) & $21,75^{a}$ & $20,50^{b}$ & $20,00^{b}$ & $20,25^{b}$ & $20,25^{b}$ & 0,23 \\
\hline Bobot lemak abdominal & (g/ekor) & $56,00^{\mathrm{a}}$ & $52,75^{b}$ & $49,50^{c}$ & $51,75^{b}$ & $47,75^{d}$ & 0,50 \\
\hline
\end{tabular}

Keterangan:

A: Ransum tanpa tambahan sekam padi, sekam padi fermentasi dan daun sirih

B: Ransum mengandung $12,5 \%$ sekam padi

C: Ransum mengandung 12,5\% sekam padi fermentasi

D: Ransum mengandung $12,5 \%$ sekam padi dan $1 \%$ daun sirih

E: Ransum mengandung $12,5 \%$ sekam padi fermentasi dan $1 \%$ daun sirih

SEM "Standar Error of the Treatment Means"

akan menghambat kerja bakteri patogen sehingga akan meningkatkan peran mikroba yang menguntungkan dalam proses pencernaan pakan (Umpel, 1997). Wididana dan Higa (1996) menyatakan bahwa Effective Microorganism-4 yang diberikan pada ternak melalui air minum atau pakan, dapat meningkatkan jumlah mikroorganisme dalam perut ternak dan juga berfungsi untuk menekan populasi mikroorganisme patogen di dalam usus sehingga meningkatkan pertumbuhan dan produksi ternak. Sudiastra (1999) mendapatkan bahwa suplementasi 0,5\% EM-4 dalam ransum secara nyata dapat meningkatkan pertumbuhan dan efisiensi penggunaan ransum. Adanya daun sirih (Piper betle L.) mengandung total fenol dan aktivitas antioksidan cukup tinggi yaitu $107 \mathrm{mg} / 100 \mathrm{ml}$ dan 97,44\% yang dapat menghambat bakteri patogen sehingga kecernaan ransum meningkat dan zat nutrisi yang dapat diserap oleh ternak meningkat sehingga bobot potong lebih tinggi (Partama et al., 2018).

Bobot darah itik betina pada perlakuan A, B, C, D dan $\mathrm{E}$ menunjukkan hasil yang berbeda tidak nyata $(\mathrm{P}>0,05)$. Hal ini disebabkan karena pemotongan ternak itik dilakukan pada umur yang sama dengan jenis kelamin itik yang sama yaitu betina, serta konsumsi ransum menunjukkan tidak berbeda nyata (Lampiran 1). Menurut Ganong (1998) volume darah dipengaruhi umur dan ukuran tubuh.

Hasil penelitian menunjukkan bobot kepala pada pelakuan $\mathrm{D}$ dan $\mathrm{E}$ dan bobot kaki pada perlakuan $\mathrm{C}$ dan $\mathrm{E}$ berbeda nyata $(\mathrm{P}<0,05)$ lebih tinggi dibandingkan dengan perlakuan A dan B karena berat potong pada perlakuan $\mathrm{C}, \mathrm{D}$ dan $\mathrm{E}$ yang lebih tinggi sehingga memberikan bobot kepala dan kaki yang lebih tinggi. Soeparno (2009) melaporkan bobot potong akan berpengaruh terhadap bobot karkas dan non karkas. Hal ini sangat dipengaruhi oleh konsumsi protein dan kecernaan protein ransum yang lebih tinggi (Lampiran 1) yang dapat mempengaruhi bobot kepala dan kaki pada pemberian perlakuan C, D dan E lebih tinggi daripada perlakuan yang lainnya. Soeparno (2005) menyatakan bahwa pertumbuhan non karkas sangat dipengaruhi oleh banyak sedikitnya protein yang dikonsumsi dan dimanfaatkan tubuh ternak.

Bobot bulu itik pada perlakuan B, C, D dan E secara statistik berbeda nyata $(\mathrm{P}<0,05)$ dibandingkan dengan pemberian perlakuan A. Hal ini karena konsumsi protein dan kecernaan protein ransum lebih tinggi daripada pemberian perlakuan A (Lampiran 1) sehingga bobot bulu pada perlakuan B, C, D dan E lebih tinggi daripada pemberian perlakuan A. Menurut Soeparno (2005) pertumbuhan bulu sangat dipengaruhi oleh protein ransum, bobot badan dan umur ternak. Semakin bertambah umur dan bobot pada itik semakin banyak protein yang diperlukan. Spearman (1992) melaporkan bahwa pertumbuhan bulu pada unggas sangat dipengaruhi oleh tingkat protein dalam ransum.

Pemberian perlakuan B, C, D dan E menurunkan secara nyata $(\mathrm{P}<0,05)$ bobot lemak perut, lemak empedal dan lemak usus dibandingkan dengan perlakuan A, sedangkan pemberian perlakuan E menghasilkan bobot lemak usus paling rendah dibandingkan dengan perlakuan lainnya. Adanya sekam padi dalam ransum dapat mengikat lemak dan diekskresikan melalui feses sehingga lemak abdominal lebih rendah. Disamping itu flavonoid yang terdapat pada daun sirih dapat menurunkan kadar kolesterol darah dengan cara meningkatkan ekskresi asam empedu dan mengurangi kekentalan (viskositas) darah sehingga mengurangi terjadinya pengendapan lemak pada pembuluh darah (Carjavall-zarrabal and Waliszewski, 2005). Daun sirih menurunkan kolesterol dengan cara penghambatan biosintesa kolesterol hepatik dan mengurangi absorpsi 
lipid di usus (Anna, 2005). Zat antioksidan pada daun sirih menurunkan lemak abdominal karena lemak dapat diikat oleh zat antioksidan yang dikandung oleh daun sirih sehingga lemak yang terakumulasi pada perut, empedal dan usus menurun. Artadana et al. (2016) mendapatkan bahwa pemberian 10\% dan 15\% kulit ubi jalar ungu difermentasi Aspergillus niger dalam ransum dapat menurunkan lemak abdominal secara nyata. Penelitian ini sesuai dengan hasil penelitian yang dilakukan oleh Januarta et al. (2016) bahwa pemberian ampas tahu terfermentasi oleh probiotik dalam ransum dapat menurunkan jumlah lemak abdomen ayam broiler.

\section{SIMPULAN}

Berdasarkan hasil penelitian ini dapat disimpulkan bahwa pemberian sekam padi tanpa dan dengan fermentasi yang disuplementasi daun sirih pada pakan itik bali betina meningkatkan bobot potong dan bobot non kerkas eksternal serta menurunkan berat lemak abdominal.

\section{DAFTAR PUSTAKA}

Anna, G., and J. Korezak. 2005. Camellia sinensis $L$ as Antioxidants in lipid systems. Trends Food Sci. Tech 16:351-358.

Artadana , I G., T. G.. B. Yadnya, dan M. Dewantari 2016. Pengaruh Pemanfaatan Kulit Ubi Jalar Ungu Terfermentasi dalam Ransum Terhadap Karkas dan Lemak Abdominal Itik Bali. Fakultas Peternakan. Universitas Udayana. Bali.

Carjavall-zarrabal and O., Waliszewski, S.M. 2005. The Consumption of Hibiscus Sabdariffa Dried Calyx Ethanolic Extract Reduced Lipid Profile in Rats. Plant Foods for Human Nutrition.

Close, W. and K. H. Menke. 1986. Selected Topics in Animal Nutrition. A Manual Prepared for The Third Hohenheim Course on Animal Nutrition in The Tropics and Semi-Tropics. 2nd Ed. The Institute of Animal Nutrition, Hohenheim University. Stuttgart.

Direktorat Jenderal Peternakan dan Kesehatan Hewan 2016. Statistik Peternakan dan Kesehatan Hewan. Direktorat Jendral Peternakan dan Kesehatan Hewan, Kementrian Pertanian. Republik Indonesia.

Ganong, W. F. 1998. Buku Ajar Fisiologi Kedokteran (Review of Medical Physiology). Terjemahan dari M. Djauhari Widjajakusumah, Edisi I7. Jakarta: EGC.

Januarta, I P., I G. N. G Bidura, dan A. A. P. P. Wibawa. 2016. Pengaruh Penggunaan Ampas Tahu Yang Difermentasi Dengan Saccharomyces Sp. Pada Ransum Terhadap Jumlah Lemak Abdomen dan Kadar Kolesterol Ayam Broiler. Fakultas Peternakan. Universitas Udayana. Bali.

Judoamidjojo, R. M., E. G. Said dan L. Hartoto. 1989. Biokonversi. Departemen Pendidikan dan Kebudayaan, Direktorat Pendidikan Tinggi. Pusat Antar Universitas Bioteknologi, Institut Pertanian Bogor. Bogor.

Lawrence, T. L. J. 1980. Growth in Animal. Butter Worths. London.

Muchtadi, T. R. dan Sugiyono. 1992. Ilmu Pengetahuan Bahan Pangan, PAU, IPB. Bogor

Murtidjo, B. A. 2006. Pengendalian Hama dan Penyakit Ayam. Penerbit Kanisius. Yogyakarta.

Morran, E. T. and H. C. Orr. 1970. Influence of strain on the yield of comercial part from the chicken broiler carcass. Poult. Sci.58-725

Partama, I. B. G., T. G. B. Yadnya, A. A. A. S Trisnadewi, A. A. P. P. Wibawa, dan I M. Mudita. 2018. Kajian Pemanfaatan Sekam Padi yang Difermentasi Effective Microorganism-4 (EM4) Di Suplementasi Daun Sirih (Piper betle L) Terhadap Performans dan Karkas Itik Bali Umur 22 Minggu. Majalah Ilmiah Peternakan, 96-102, Oct. 2018. Available: https://ojs.unud.ac.id/index.php/mip/article/ view/46058/27889 DOI: https://doi.org/10.24843/ MIP.2018.v21.io3.po2

Setioko, A. R., dan E. S. Rohaeni. 2001. Pemberian Ransum Bahan Pakan Lokal terhadap Produktivitas Itik Alabio. Lokakarya Unggas Air Nasional. Fakultas Peternakan IPB dan Balai Penelitian Ternak di Ciawi tanggal 6-7 Agustus 2001.

Soeparno. 2005. Ilmu dan teknologi daging cetakan keempat. Gadjah Mada University Press, Yogyakarta.

Soeparno. 2009. Ilmu dan Teknologi Daging. Universitas Gajah Mada Press, Yogyakarta.

Sudiastra, I. W. 1999. Suplementasi probiotik dalam ransum berprotein rendah terhadap penamplian ayam. Majalah Ilmiah Peternakan, Vol. 2 No. 1. Fakultas Peternakan. Universitas Udayana, Denpasar.

Susila, T. G. O., T. G. Belawa Yadnya, dan N. G. K. Roni. 2015. Upaya Peningkatan Nilai Nutrisi Sekam Padi melaui Amoniasi Urea dan Biofermentasi Aspergillus niger disuplementasi Daun Ubi Jalar Ungu terhadap Penampilan, Kapasitas Antioksidan, dan Kadar Kolesterol Daging Itik Fase Pertumbuhan, Laporan Penelitian Hibah Unggulam Perguruan Tinggi, Fakultas Peternakan. Universitas Udayana.

Umpel, G. J. 1997. Pengalaman Penerapan Teknologi EM4. Diseminarkan pada Seminar Nasional Pertanian Organik. Jakarta.

USDA (United State Departement of Agriculture). 1977. Poultry Guiding Manual. U.S. Government Printing Office Washington, D.C. 
Whytes, J. R. and W. R. Ramsay. 1979. Beef carcass composition and meat quality. First Edition. Queensland Departement of Primary Industries Brisbane.

Wididana. G. N. dan Higa, T. 1996. Teknologi effective microorganisms. Indonesia Kyusei Nature Farming Societies dan PT Songgolangit Persada, Jakarta.

Yadnya, T. G. B., I. B. Gaga Partama, dan A. A. A. S. Trisnadewi. 2014. Kajian Pemanfaatan Kulit Ubi Jalar Ungu (Ipomoea batatas L) Terfermentasi dalam Ransum terhadap Penampilan, Kualitas karkas, Profil Antioksidan, dan kadar kolesterol Daging Itik Bali. Laporan Penelitian Unggulan Perguruan Tinggi, Tahun Anggaran 2014.

Yadnya, T. G. B. dan I W. Wirawan. 2016. Kajian Pemanfaatan Sekam Padi Mengandung Daun Noni (Morinda citrifolia L.) disuplementasi Multienzim terhadap Kapasitas Antioksidan, Produksi Telur dan Kualitas Telur Itik Bali pada Fase Peneluran Pertama. Laporan Penelitian Hibah Unggulan Program Studi, Fakultas Peternakan, Universitas Udayana. Tahun Anggaran 2016. 